\title{
Konservasi Air Di Provinsi Kalimantan Utara (Studi Potensi Embung Di Kabupaten Bulungan)
}

\author{
Enny Harviyanti ${ }^{1}$, Zainal Abidin ${ }^{2}$, Nofrizal ${ }^{3}$ \\ ${ }^{1}$ Jurusan Teknik Sipil Universitas Kaltara, Tanjung Selor \\ Email:enny.harviyanti@yahoo.com \\ ${ }^{2}$ Jurusan Teknik Sipil Universitas Kaltara, Tanjung Selor \\ Email:Zainal.Abidin@gmail.com \\ ${ }^{3}$ Jurusan Teknik Sipil Universitas Kaltara, Tanjung Selor \\ Email : Nofrizal.Unikal@gmail.com
}

\begin{abstract}
ABSTRAK
Tujuan studi ini untuk menginventarisasi sungai-sungai yang potensial dijadikan lokasi embung untuk memenuhi kebutuhan air penduduk di sekitarnya dan mengetahui debit yang tersedia pada sungai tersebut. Metodologi yang digunakan adalah pengumpulan data dari instansi terkait, survei lapangan, pemilihan lokasi embung dan analisis kebutuhan \& ketersediaan air di sungai. Berdasarkan kriteria pemilihan lokasi embung dengan ketiga aspek, nilai modifikasi bobot pertimbangan dan pertimbangan salah satu aspek saja maka disimpulkan nilai lokasi yang tertinggi adalah Embung Tanjung Palas. Neraca air Embung Tanjung Palas menunjukkan bagaimana kriteria dari aspek teknis dan non teknis memiliki rangking tertinggi.
\end{abstract}

Kata Kunci : Daerah Aliran Sungai, Nilai lokasi dan neraca air

\begin{abstract}
The purpose of this study is to make an inventory of potential rivers to be used as reservoir locations to meet the water needs of the surrounding population and to determine the available discharge on the river. The methodology used is data collection from relevant agencies, field surveys, selection of reservoir locations and analysis of water needs \& availability in rivers. Based on the selection criteria for the reservoir location with the three aspects, the value of the modified weight consideration and consideration of just one aspect, it is concluded that the highest location value is the Tanjung Palas Embung. Tanjung Palas Embung water balance shows how the criteria from the technical and non-technical aspects have the highest rank.
\end{abstract}

Keywords: Watershed, location value and water balance.

\section{PENDAHULUAN}

Dalam rangka pemanfaatan potensi sumber daya air dan meningkatkan kesejahteraan penduduk melalui pelaksanaan pembangunan nasional maka perlu upaya pembangunan prasarana yang menyangkut aspek : pengembangan potensi sumber air menjadi sumber air buatan (embung atau waduk) dan pemanfaatan sumber air guna memenuhi berbagai keperluan akan air (air baku bagi rumah tangga, siram tanaman, kebutuhan ternak dan lain sebagainya.

Memperhatikan kondisi topografi di Kabupaten Bulungan yang berbukit-bukit dan di sela-sela tebing terdapat aliran sungai yang memilik potensi dapat di tingkatkan potensinya. Sebagian besar curah hujan yang terjadi dalam hujan badai yang hanya terjadi beberapa kali sehingga menyebabkan banjir besar yang selanjutnya terbuang ke laut. Mata air yang merupakan sumber aliran dasar sungai sangat jarang dijumpai di musim kering. Untuk mengatasi kekurangan air pada musim kering dan menyimpan air pada musim hujan diperlukan suatu bangunan pengendali seperti embung. Selama musim kering air dapat dimanfaatkan untuk memenuhi kebutuhan penduduk, ternak dan kebun.

Wilayah Sungai Kayan merupakan bagian dari enam wilayah sungai yang secara administratif meliputi dua kabupaten, yaitu Kabupaten Malinau dan Bulungan Provinsi Kalimantan Utara. Di sepanjang Wilayah Sungai Kayan mengalir sungai besar dan kecil tidak kurang dari ratusan sungai dan bermuara ke laut Sulawesi. Sungai-sungai tersebut sangat potensial dikembangkan sebagai sumber daya air untuk memenuhi kebutuhan air penduduk.

Tujuan studi ini adalah menginventarisasi sungai-sungai yang potensial dijadikan lokasi embung untuk memenuhi kebutuhan air penduduk di sekitarnya dan untuk mengetahui jumlah ketersediaan air pada sungai tersebut. 


\section{TINJAUAN PUSTAKA}

\subsection{Debit Andalan/Ketersediaan Air}

Beberapa metode dapat dilakukan untuk mengetahui debit andalan ini seperti metode empiris (FJ. Mock dan SMEC) dan pengukuran langsung di lokasi dengan memasang alat pengukur debit Automatic Water Level Record (AWLR)

a. Pengukuran di lokasi

Debit sesat di lokasi calon embung dilakukan dengan bantuan alat pengukur kecepatan (currentmeter). Hasil pengukuran kecepatan dikalikan dengan luas penampang basah sungai untuk mendapatkan debit. Hal ini dilakukan beberapa kali pengukuran dan di beberapa titik pengamatan.

b. Metode Empiris (SMEC)

Metode SMEC pertama kali dibuat oleh Konsultan SMEC pada tahun 1982 yang didasarkan pada jenis tanah daerah tangkapan (Catchment area). Metode SMEC dikembangkan dalam 2 zona yang dibedakan menurut kondisi geologinya, yaitu zona A dan zona B.

- Zona A Sebagian besar daerah pengaliran saat terjadinya hujan, pengisian air tanah akan terjadi secara perlahan - lahan, sehingga debit sungai cepat naik. Persamaan yang digunakan adalah :

$$
\begin{aligned}
& \mathrm{Q} 2=\mathrm{A}(0,210 \mathrm{MMR}-8,50) \times 10^{-3}, \text { untuk } \mathrm{MMR} \leq 250 \mathrm{~mm} \\
& \mathrm{Q} 2=\mathrm{A}(0,366 \mathrm{MMR}-47,5) \times 10^{-3}, \text { untuk MMR } \geq 250 \mathrm{~mm}
\end{aligned}
$$

- Zona B Sebagian daerah pengaliran sungai, air tanah terjadi dengan cepat. Adapun persamaan yang digunakan adalah:

$\mathrm{Q} 2=\mathrm{A}(0,20 \mathrm{PI}) \times 10^{-3}$, untuk PI $<300 \mathrm{~mm}$

$\mathrm{Q} 2=\mathrm{A}(0,32 \mathrm{PI}-36,0) \times 10^{-3}$, untuk PI $\geq 300 \mathrm{~mm}$

$\mathrm{PI}=(1 / 3 \mathrm{MMR}+2 / 3 \mathrm{MMR}$ sebelumnya)

Untuk aliran zona A dan zona B:

$\mathrm{Q} 5=0,75 \times \mathrm{Q} 2$

c. Metode FJ. Mock

Prinsip dasar metode ini didasarkan pada hujan yang jatuh pada catchment area sebagian akan hilang sebagai evapotranspirasi, sebagian langsung menjadi aliran permukaan dan sebagian lagi akan masuk ke dalam tanah (infiltrasi). Proses infiltrasi pada tahap pertama akan menjenuhkan tanah permukaan dan menjadi perkolasi membentuk air bawah permukaan (ground water) yang selanjutnya akan keluar di sungai sebagai aliran dasar (base flow).

Persamaan yang digunakan antara lain adalah :

$$
\mathrm{Q}=(\mathrm{Dro}+\mathrm{Bf}) \mathrm{A}
$$

\subsection{Kebutuhan Air Bersih}

a. Karakteristik pemakaian air pemakaian air secara garis besar dapat dikelompokkan dalam:

- Pemakaian air bersih untuk kebutuhan rumah tangga (domestik).

1) Sambungan langsung atau sambungan rumah (SR).

Berdasarkan pada ketentuan yang digunakan oleh Dirjen Pengembangan Perkotaan Departemen KIMPRASWIL, untuk kebutuhan air bersih:

a) Kota Metro dengan jumlah penduduk $=>1000000$ jiwa sebesar 190 liter/hari/orang

b) Kota besar dengan jumlah penduduk $=500001-1000000$ jiwa sebesar 170 liter/hari/orang

c) Kota sedang dengan jumlah penduduk $=100001-500000$ jiwa sebesar 150 liter/hari/orang

d) Kota kecil dengan jumlah penduduk $=10001-100000$ jiwa sebesar 130 liter/hari/orang

2) Sambungan tidak langsung atau kran umum (KU). Dimana satu buah kran umum akan melayani 200 jiwa penduduk dengan pemakaian air rata-rata 30 liter/orang/hari.

- Pemakaian air untuk kebutuhan sosial.

1). Kebutuhan air untuk fasilitas pendidikan sebesar 10 liter/orang/hari

2). Kebutuhan air untuk fasilitas perkantoran sebesar 10 liter/orang/hari

3). Kebutuhan air untuk rumah sakit $12 \mathrm{~m}$ /unit/hari

4). Fasilitas kesehatan lainnya kebutuhan air sebesar 1000 liter/unit/hari

5). Kebutuhan air untuk fasilitas ibadah sebesar $2 \mathrm{~m}^{3} /$ hari/unit

6). Kebutuhan air untuk fasilitas perdagangan sebesar $12 \mathrm{~m}^{3} / \mathrm{ha} / \mathrm{hari}$

- Pemakaian air untuk kebutuhan industri. Pemakaian air untuk kebutuhan industri mempunyai pengaruh yang cukup besar terhadap kebutuhan air secara keseluruhan. Jumlah kebutuhan air tergantung dari jenis industrinya. Untuk industri yang 
tidak terlalu besar memerlukan jumlah air sebesar $5 \%$ dari kebutuhan rumah tangga.

- Pemakaian air untuk umum dan kehilangan air

Pemakaian air yang dapat di kategorikan sebagai kebutuhan umum adalah untuk penyiraman tanaman, sanitasi, pemadam kebakaran, dan lainnya. Sedangkan kehilangan air disebabkan oleh adanya kebocoran pada pipa distribusi, sambungan ilegal, kerusakan atau ketidaktepatan pembacaan meteran. Besarnya angka kehilangan air pada umumnya ditetapkan berkisar antara: $20 \%$ untuk sistem baru dan $30-50 \%$ untuk sistim lama.

b. Fluktuasi Kebutuhan Air

Untuk faktor kebutuhan air pada hari maksimum ini ditetapkan berkisar antara 1,15-1,20. Sedangkan untuk faktor kebutuhan air pada jam puncak berkisar antara 1,75 - 2,00.

\subsection{Kriteria pengembangan}

Perlu dilakukan suatu skala prioritas dalam pengembangan suatu embung dengan cara kriteria praktis dalam pemilihan lokasi sehingga didapatkan suatu hasil yang optimal. Adapun kriteria tersebut adalah:

a. Luas Daerah Aliran Sungai (DAS) lebih kecil dari $10 \mathrm{~km}^{2}$ untuk tiap onstream reservoir

b. Di daerah irigasi tadah hujan/irigasi sederhana yang telah ada dan dimanfaatkan untuk:

- Sawah tadah hujan/irigasi desa

- Lahan untuk tanaman palawija/sayur mayur

- Lahan untuk ladang penggembalaan

c. Pengadaan air bersih untuk desa

- Jarak desa/komplek pemukiman tidak lebih dari $5 \mathrm{~km}$ dari lokasi

- Desa tersebut belum ada program air bersih atau bermasalah kekurangan air bersih di musim kemarau, diutamakan desa tertinggal

d. Tinggi embung maksimum $8 \mathrm{~m}$ atau volume tampungan 1 juta $\mathrm{m}^{3}$

e. Bahan timbunan utama tersedia di dekat site

f. Untuk bahan kedap air (lempung) tersedia pada jarak lebih kecil dari $5 \mathrm{~km}$ dari site embung

g. Lahan manfaat harus mengacu pada Tata Ruang Daerah

h. Dapat diterima baik oleh masyarakat pemakai air setempat

- $\quad$ Bobot pertimbangan Dalam pertimbangan pemilihan lokasi embung ditinjau dua aspek seperti pada Tabel 1.

Tabel 1. Bobot Pertimbangan Pemilihan Lokasi Embung

\begin{tabular}{|c|l|c|}
\hline No. & \multicolumn{1}{|c|}{ Aspek Teknis } & $\begin{array}{c}\text { Bobot } \\
\text { Pertimbangan }\end{array}$ \\
\hline 1 & Bentang As Embung & $3 \%$ \\
\hline 2 & Volume Tampungan $\left(\mathrm{m}^{3}\right)$ & $8 \%$ \\
\hline 3 & Jarak Ketersediaan Material (m) & $9 \%$ \\
\hline 4 & Baseflow & $3 \%$ \\
\hline 5 & Kondisi Geologi & $6 \%$ \\
\hline 6 & Jalan Masuk Ke Lokasi Site & $8 \%$ \\
\hline 7 & Kondisi Daerah Aliran Sungai & $5 \%$ \\
\hline 8 & Jarak Daerah Layanan (m) & $8 \%$ \\
\hline 9 & Lokasi Embung & $6 \%$ \\
\hline 10 & Sistem Distribusi Air & $8 \%$ \\
\hline
\end{tabular}

\begin{tabular}{|c|l|c|}
\hline No. & \multicolumn{1}{|c|}{ Aspek Non Teknis } & $\begin{array}{c}\text { Bobot } \\
\text { Pertimbangan }\end{array}$ \\
\hline 1 & Manfaat (Air Baku/Irigasi) & $11 \%$ \\
\hline 2 & Kondisi Masyarakat Penerima Manfaat & $4 \%$ \\
\hline 3 & Pencapaian Lokasi & $5 \%$ \\
\hline 4 & Kepemilikan Lahan & $4 \%$ \\
\hline 5 & Dampak Lingkungan & $7 \%$ \\
\hline 6 & Tanggapan Masyarakat & $8 \%$ \\
\hline 7 & Prioritas Kebutuhan Penduduk & $6 \%$ \\
\hline 8 & Kemudahan Dalam Pembebasan Lahan & $10 \%$ \\
\hline
\end{tabular}


Pemberian nilai bobot pertimbangan berdasarkan besaran-besaran yang telah dapat diterima pada beberapa studi embung seperti yang dilakukan oleh Balai Wilayah Sungai.

- Nilai Lokasi

a) Aspek Teknis

Bentang As Embung (3\%)

- Jika Bentang As Embung Memiliki Panjang 30-70 m memiliki nilai antara 10-8

- Jika Bentang As Embung Memiliki Panjang 70-100 m memiliki nilai antara 7-4

- Jika Bentang As Embung Memiliki Panjang > 100 m memiliki nilai antara 3-0

Volume Tampungan $\left(\mathrm{m}^{3}\right)$

- Jika Volume Tampungan Embung $>100.000 \mathrm{~m}^{3}$ memiliki nilai antara 10-8

- Jika Volume Tampungan Embung berada di antara 40.000 - $100.000 \mathrm{~m}^{3}$ memiliki nilai antara 7-4

- $\quad$ Jika Volume Tampungan Embung <40.000 $\mathrm{m}^{3}$ memiliki nilai antara 3-0

Jarak Ketersediaan Material (Batuan \& Tanah Urugan)

- Jarak tempuh pengambilan material batuan berjarak <500 m memiliki nilai 10-8

- Jarak tempuh pengambilan material batuan berjarak antara 500-1000 m memiliki nilai 7-4

- Jarak tempuh pengambilan material batuan berjarak >1000 m memiliki nilai 3-0

Baseflow Ketersediaan

- $\quad$ Tidak ada baseflow memiliki nilai 10-8

- Baseflow hanya tersedia sampai bulan Juni (6 Bulan) memiliki nilai 7-4

- Baseflow selalu ada sepanjang tahun memiliki nilai 3-0

Kondisi Geologi

- $\quad$ Kondisi geologi memiliki klasifikasi permeabel memiliki nilai 10-8

- Kondisi geologi memiliki klasifikasi semi permeabel memiliki nilai 7-4

- Kondisi geologi memiliki klasifikasi impermeabel memiliki nilai 3-0

Jalan Akses Masuk Ke Lokasi Site

- $\quad$ Kondisi akses jalan masuk ke lokasi berjarak 0-300 memiliki nilai 10-8

- Kondisi akses jalan masuk ke lokasi berjarak 300-1000 memiliki nilai 7-4

- Kondisi akses jalan masuk ke lokasi berjarak >1000 memiliki nilai 3-0

Kondisi Daerah Aliran Sungai

- $\quad$ Kondisi tata guna lahan di daerah aliran sungai kondisi baik memiliki nilai 10-8

- Kondisi tata guna lahan di daerah aliran sungai kondisi sedang memiliki nilai 7-4

- Kondisi tata guna lahan di daerah aliran sungai kondisi jelek memiliki nilai 3-0

Jarak Daerah Layanan Dari Lokasi Embung

- Jarak daerah layanan baik untuk irigasi maupun suplai air baku ke lokasi pemanfaat jika <1000 m memiliki 10-8

- Jarak daerah layanan baik untuk irigasi maupun suplai air baku ke lokasi pemanfaat jika 1000-2000 m memiliki 7-4

- Jarak daerah layanan baik untuk irigasi maupun suplai air baku ke lokasi pemanfaat jika >2000 m memiliki 3-0

Situasi Lokasi Site Embung

- $\quad$ Situasi topografi merupakan cekungan memiliki nilai 10-8

- $\quad$ Situasi topografi merupakan curah/alur sungai memiliki nilai 7-4

- $\quad$ Situasi topografi merupakan sungai memiliki nilai 3-0

Sistem Distribusi Air

- $\quad$ Sistem suplai memanfaatkan gravitasi topografi memiliki nilai 10-8

- Sistem suplai dimanfaatkan dengan cara di ambil sendiri, memiliki nilai 7-4

- $\quad$ Sistem suplai menggunakan sistem ompa memiliki nilai 3-0

b) Aspek Non Teknis

Kemanfaatan

- Manfaat embung untuk air baku dan irigasi memiliki nilai 10-8

- Manfaat embung untuk air baku memiliki nilai 7-4

- $\quad$ Manfaat embung untuk irigasi memiliki nilai 3-0

Kondisi Masyarakat Penerimaan Manfaat

- Secara sosial kondisi masyarakat penerima secara ekonomi masuk dalam pra sejahtera memiliki nilai 10-8

- Secara sosial kondisi masyarakat penerima secara ekonomi masuk dalam sejahtera I memiliki nilai 7-4

- Secara sosial kondisi masyarakat penerima secara ekonomi masuk dalam sejahtera II memiliki nilai 3-0

Akses Menuju Lokasi

- $\quad$ Bisa menggunakan kendaraan roda 4 ke lokasi site embung memiliki nilai 10-8

- $\quad$ Bisa menggunakan kendaraan roda 2 ke lokasi site embung memiliki nilai 7-4

- $\quad$ Bisa menggunakan jalan kaki ke lokasi site embung memiliki nilai 3-0 
Kepemilikan Tanah

- $\quad$ Lahan lokasi embung dimiliki oleh pemerintah memiliki nilai 10-8

- $\quad$ Lahan lokasi embung dimiliki oleh pemerintah dan penduduk memiliki nilai 7-4

- $\quad$ Lahan lokasi embung dimiliki oleh penduduk memiliki nilai 3-0

Dampak Lingkungan

- Memberikan dampak positif untuk konservasi lingkungan memiliki nilai 10-8

- $\quad$ Tidak memberikan dampak untuk konservasi lingkungan memiliki nilai 7-4

- Memberikan dampak negatif untuk konservasi lingkungan memiliki nilai 3-0

Tanggapan Masyarakat

- $\quad$ Masyarakat menerima terhadap kegiatan pembangunan embung memiliki nilai 10-8

- Masyarakat acuh tak acuh terhadap kegiatan pembangunan embung memiliki nilai 7-4

- Masyarakat acuh tidak menerima terhadap kegiatan pembangunan embung memiliki nilai 3-0

Prioritas Kebutuhan Penduduk

- $\quad$ Penduduk kondisi di tahap sangat membutuhkan memiliki nilai 10-8

- $\quad$ Penduduk kondisi di tahap membutuhkan memiliki nilai 7-4

- $\quad$ Penduduk kondisi di tahap tidak membutuhkan memiliki nilai 3-0

Kemudahan Dalam Pembebasan Lahan

- $\quad$ Tanpa ganti rugi memiliki nilai 10-8

- $\quad$ Mudah ganti rugi memiliki nilai 7-4

- Sulit dalam ganti rugi memiliki nilai 3-0

- Perhitungan Nilai

Perhitungan nilai lokasi embung dilakukan secara tabel. Nilai relatif adalah bobot penilaian dikalikan nilai masingmasing parameter. Total nilai dari masing-masing aspek adalah jumlah nilai relatif. Nilai lokasi adalah total nilai dikalikan bobot pertimbangan dibagi dengan total bobot penilaian. Total nilai lokasi adalah jumlah dari nilai lokasi dari setiap aspek.

- Analisa Kepekaan/Sensitivitas

Uji sensitivitas dilakukan dengan mengubah bobot pertimbangannya:

a. Bobot pertimbangan semua aspek dianggap sama, yakni 0,25

b. Hanya menilai aspek teknis saja, bobot pertimbangan teknis $=1$, sedangkan aspek lainnya tidak dipertimbangkan $(=0)$

c. Hanya menilai aspek irigasi dan pertaniannya saja, bobot irigasi \& pertanian $=1$

d. Hanya mempertimbangkan aspek ekonomi saja, bobot ekonomi $=1$

e. Hanya mempertimbangkan aspek lingkungan, bobot pertimbangannya $=1$

\section{METODOLOGI}

\subsection{Deskripsi Lokasi Studi}

Penelitian ini mengambil lokasi di Kabupaten Bulungan Provinsi Kalimantan Utara.

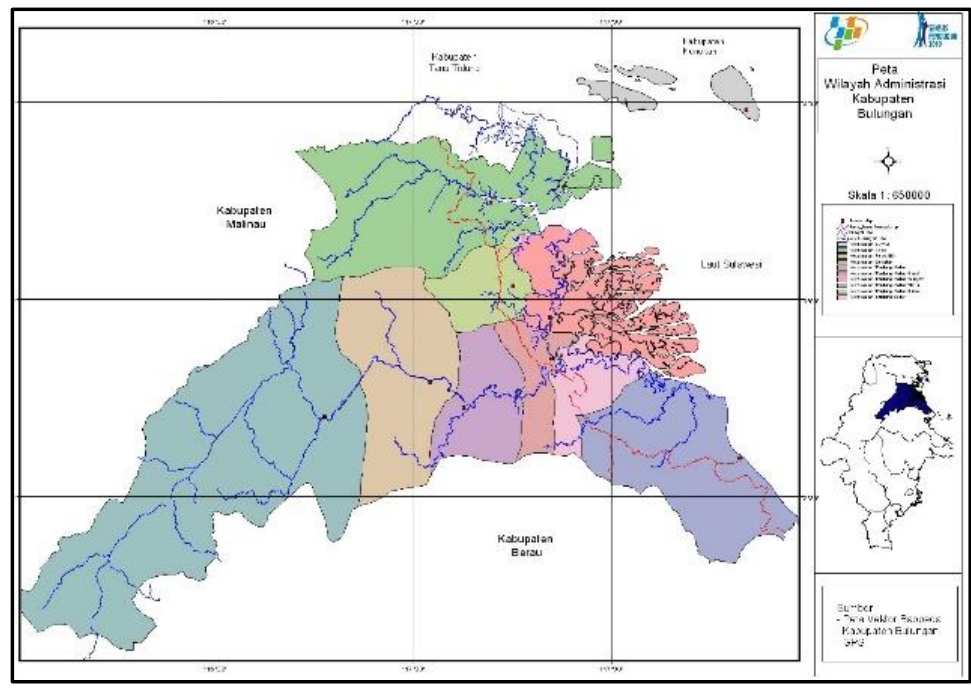

Gambar 1. Peta Wilayah Kabupaten Bulungan 
- Letak Posisi :

Lintang Utara : 2॰09'19'-3³4'49"

Bujur Timur : $116^{\circ} 04^{\prime \prime} 41^{\prime \prime}-117^{\circ} 57^{\prime} 56^{\prime \prime}$

- Batas Wilayah :

Sebelah Utara : Kabupaten Tana Tidung dan Kabupaten Nunukan

Sebelah Timur : laut Sulawesi dan Kota Tarakan

Sebelah Selatan: Kabupaten Berau

Sebelah Barat: Kabupaten Malinau

- $\quad$ Luas Wilayah : $13.181,92 \mathrm{Km}^{2}$

\subsection{Pengumpulan Data}

Data yang diperlukan dalam penelitian ini berupa data primer dan data sekunder. Data sekunder yang didapat dari stakeholder yang terkait, berupa :

a) Peta rupa bumi skala 1: 50.000

b) Data hujan dipakai stasiun yang terdekat yakni Stasiun Tanjung Harapan, Tanjung Selor.

c) Data klimatologi dipakai stasiun klimatologi Stasiun Tanjung Harapan, Tanjung Selor.

\subsection{Analisis Data}

a) Dari peta skala $1: 50.000$ ditentukan potensi daerah lokasi calon embung, baik embung off stream maupun on stream .

b) Data hujan, klimatologi dan luas Daerah Aliran Sungai (DAS) digunakan untuk menentukan ketersediaan air di sungai.

Dari peta skala 1: 50.000 yang telah ditentukan calon lokasi embung, selanjutnya dilakukan survei lapangan yang meliputi:

a) Survei kondisi site calon embung, berupa: fondasi (dasar sungai, tebing kiri dan kanan sungai), tipe calon embung, vegetasi daerah genangan, pembebasan tanah dan membuat sketsa site embung.

b) Survei hidrologi/hidrometri, berupa: luas DAS, panjang sungai, kondisi hutan (kritis, sedang, bagus), pengukuran debit sesaat. secara visual (kritis, sedang, rendah) di DAS, dasar sungai, tebing kiri dan kanan sungai, bahan sedimen sungai (batu, kerikil, pasir, liat, lanau), ada tidaknya sumber mata air, tingkat kebocoran tampungan (besar, sedang, kecil) dan jarak lokasi calon embung ke desa terdekat

c) Survei lokasi, berupa : nama kampung, nama sungai, pencapaian ke lokasi

d) Survei geologi permukaan, berupa: kondisi batuan, sumber material konstruksi

Hasil survei tersebut digunakan sebagai bahan untuk pemilihan lokasi calon embung dengan mempertimbangkan keempat aspek seperti yang telah diuraikan sebelumnya. Prioritas pengembangan dapat diketahui dengan melakukan uji kepekaan/sensitivitas terhadap nilai lokasi embung.

\section{HASIL DAN PEMBAHASAN}

\subsection{Hasil Penelitian}

Berdasarkan hasil investigasi lapangan diperoleh 4 lokasi yang berpotensi yaitu berlokasi di Kecamatan Tanjung Palas, Tanjung Palas Tengah, Tanjung Palas Timur dan Bunyu.

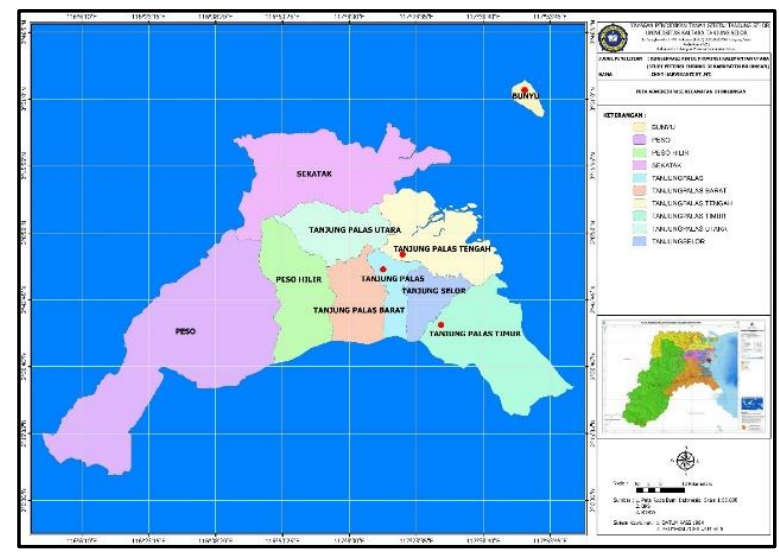

Gambar 2. Lokasi Penelitian Embung

Dengan menggunakan bantuan software Global Mapper untuk mendapatkan kontur dan besarnya tampungan serta ArcGIS untuk mencari luas DAS, diperoleh analisa sebagai berikut : 


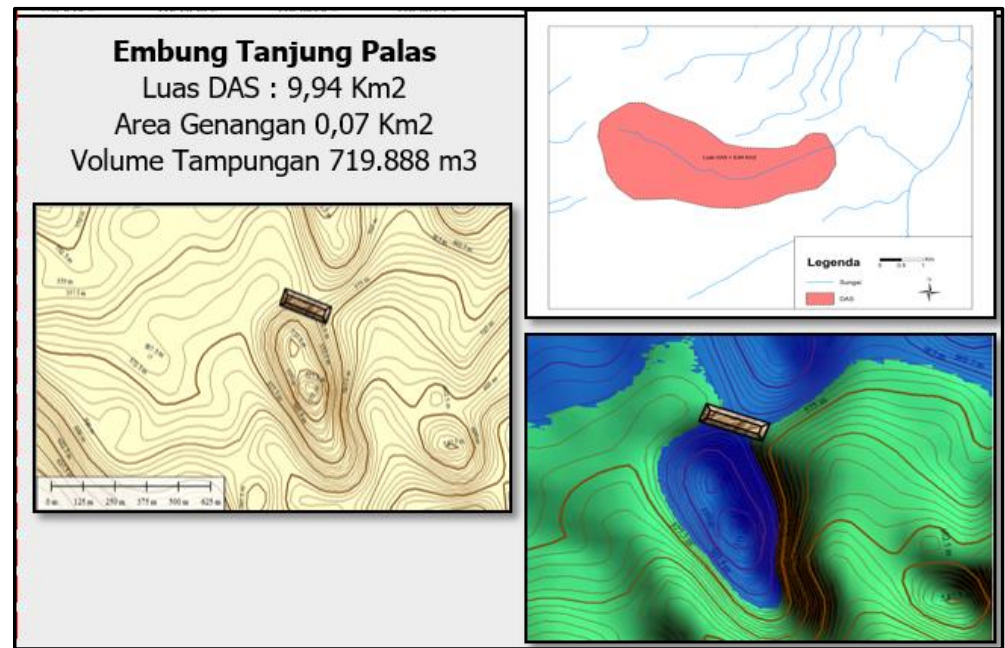

Gambar 3. Lokasi Embung Tanjung Palas

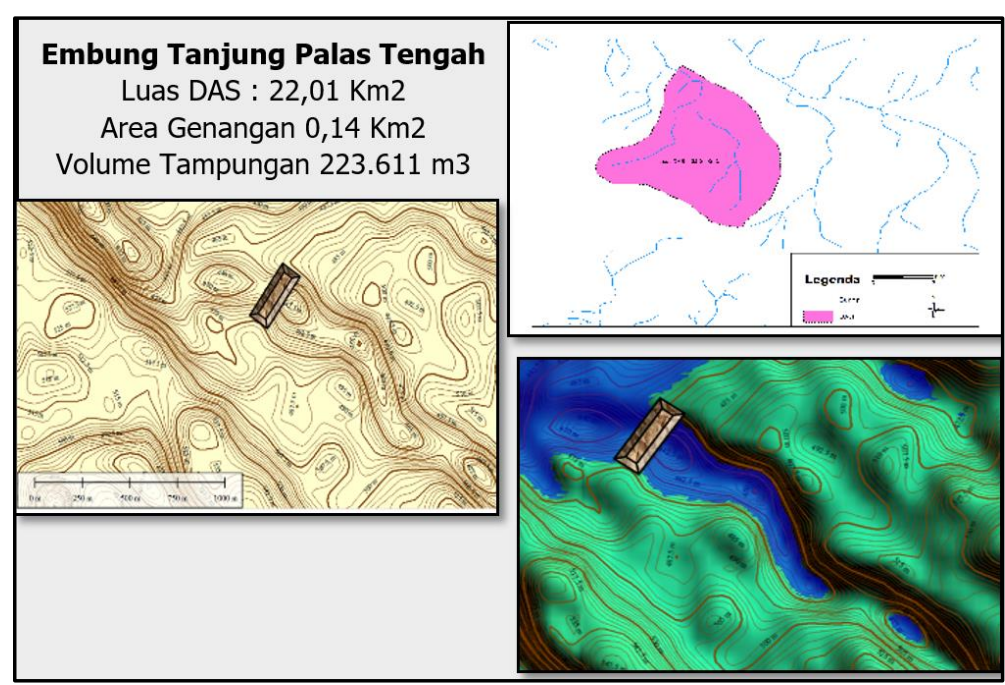

Gambar 4. Lokasi Embung Tanjung Palas Tengah

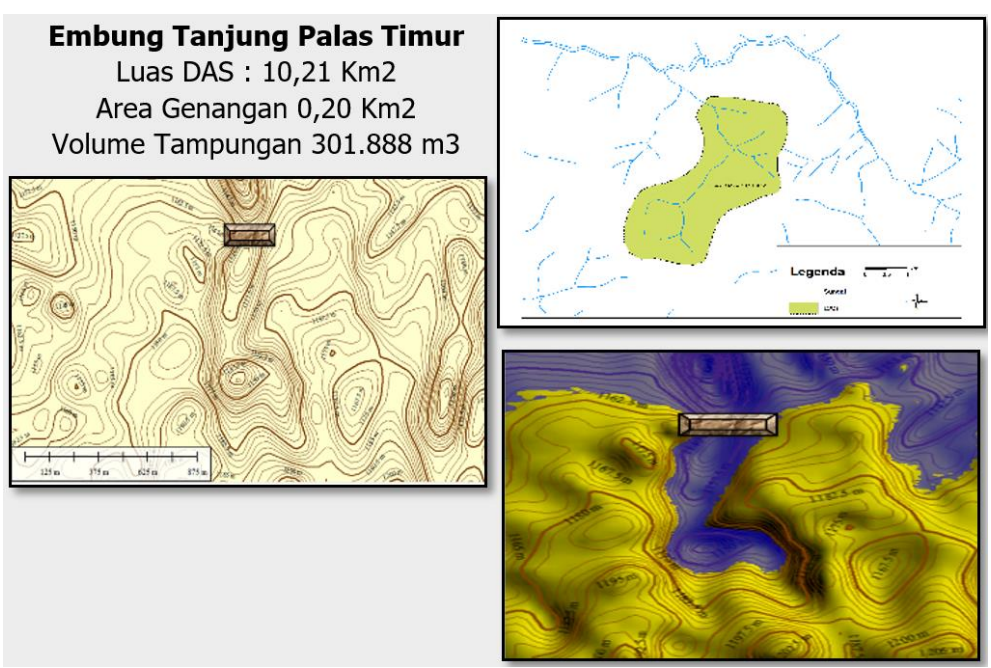

Gambar 5. Lokasi Embung Tanjung Palas Timur 


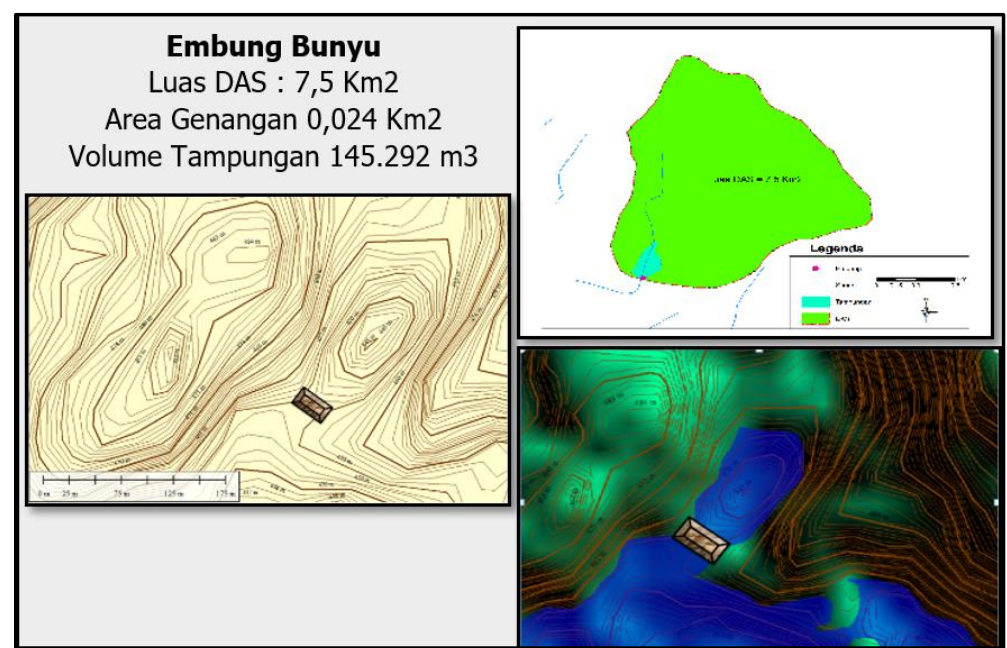

Gambar 6. Lokasi Embung Bunyu

Hasil penilaian pemilihan lokasi embung disajikan pada tabel $2 \& 3$ dan neraca air untuk nilai lokasi tertinggi (Embung Tanjung Palas) disajikan pada Tabel 4.

\subsection{Pembahasan}

Dengan menggunakan dua aspek kriteria pemilihan lokasi embung, di mana bobot untuk aspek teknis dan non teknis $(9,73 \%)$ untuk embung Tanjung Palas, $(9,17 \%)$ untuk embung Tanjung Palas Tengah, $(8,41 \%)$ untuk embung Tanjung Palas Timur dan $(8,37 \%)$ untuk embung Bunyu. Sehingga berdasarkan rangking tersebut nilai tertinggi merupakan embung Tanjung Palas.

Tabel 2. Urutan Lokasi Embung Berdasarkan Nilai Lokasi Berdasarkan Aspek Teknis \& Non Teknis

\begin{tabular}{|c|c|c|c|c|c|c|c|c|}
\hline \multirow{2}{*}{ KETERANGAN } & \multirow{2}{*}{$\begin{array}{l}\text { PENENTUAN } \\
\text { PENELITIAN }\end{array}$} & \multirow{2}{*}{$\begin{array}{c}\text { ВОВОТ (В) } \\
\text { (\%) }\end{array}$} & \multicolumn{3}{|c|}{ TANOUNG PALAS } & \multicolumn{3}{|c|}{ TANOUNG PALAS TENGAH } \\
\hline & & & IDENIIFIKASI & NILAI (N) & ( NX B)/100 & IDENIIFIKASI & NILAI (N) & $(\mathrm{NX} B) / 100$ \\
\hline ASPEK TEKNIS & & 45 & & & & & & \\
\hline $\begin{array}{l}1 \text { Bentang }(\mathrm{x} \mathrm{m}) \\
\text { a. } 30-70 \\
\text { b. } 70-100 \\
\text { c. } x>100 \\
\end{array}$ & $\begin{aligned} \text { Nilai }=10-8 \\
\text { Nilai }=7-4 \\
\text { Nilai }=3-0\end{aligned}$ & 3 & $\begin{array}{l}\text { Panjang bentang sekitar } \\
100 \mathrm{~m}\end{array}$ & 7 & 0.21 & $\begin{array}{c}\text { Panjang bentang sekitar } \\
100 \mathrm{~m}\end{array}$ & 7 & 0.21 \\
\hline $\begin{array}{l}2 \text { Volume tampungan }\left(\mathrm{m}^{3}\right) \\
\text { a. }>100.000 \\
\text { b. } 40.000-100.000 \\
\text { c. }<40.000 \\
\end{array}$ & $\begin{aligned} \text { Nilai }=10-8 \\
\text { Nilai }=7-4 \\
\text { Nilai }=3-0\end{aligned}$ & 8 & $\begin{array}{l}\text { Volume tampungan } \\
\text { sekitar } 719.888 \mathrm{~m}^{3}\end{array}$ & 9 & 0.72 & $\begin{array}{l}\text { Volume tampungan } \\
\text { sekitar } 223.611 \mathrm{~m}^{3}\end{array}$ & 7 & 0.56 \\
\hline $\begin{array}{l}3 \text { Jarak ketersediaan material }(\mathrm{m}) \\
\text { A. Batu } \\
\text { a. } 0-500 \\
\text { b. } 500-1000 \\
\text { c. }>1000 \\
\end{array}$ & $\begin{aligned} \text { Nilai }=10-8 \\
\text { Nilai }=7-4 \\
\text { Nilai }=3-0\end{aligned}$ & 3 & $\begin{array}{l}\text { Ketersediaan batu } \\
\text { sekitar } 2000 \mathrm{~m}\end{array}$ & 6 & 0.18 & $\begin{array}{l}\text { Ketersediaan batu } \\
\text { sekitar } 800 \mathrm{~m}\end{array}$ & 5 & 0.15 \\
\hline $\begin{array}{l}\text { B. Tanah } \\
\text { a. } 0-500 \\
\text { b. } 500-1000 \\
\text { c. }>1000\end{array}$ & $\begin{aligned} \text { Nilai } & =10-8 \\
\text { Nilai } & =7-4 \\
\text { Nilai } & =3-0\end{aligned}$ & 6 & $\begin{array}{c}\text { Ketersediaan Tanah < } \\
500 \mathrm{~m}\end{array}$ & 8 & 0.48 & $\begin{array}{c}\text { Ketersediaan Tanah }< \\
500 \mathrm{~m}\end{array}$ & 6 & 0.36 \\
\hline $\begin{array}{ll}4 \text { Baseflow } \\
\text { a. Tidak ada } \\
\text { b. Ada sampai bulan Juni } \\
\text { c. Ada sepanjang tahun } \\
\end{array}$ & $\begin{aligned} \text { Nilai }=10-8 \\
\text { Nilai }=7-4 \\
\text { Nilai }=3-0\end{aligned}$ & 3 & $\begin{array}{c}\text { Ada Baseflow sebesar } \\
0,039 \mathrm{~m} 3 / \mathrm{dt}\end{array}$ & 9 & 0.27 & $\begin{array}{c}\text { Ada Baseflow sebesar } \\
0,044 \mathrm{~m} 3 / \mathrm{dt}\end{array}$ & 3 & 0.09 \\
\hline $\begin{array}{l}5 \text { Kondisi geologi } \\
\text { a. Permeabel } \\
\text { b. Semi Permeabel } \\
\text { c. Impermeabel } \\
\end{array}$ & $\begin{aligned} \text { Nilai }=10-8 \\
\text { Nilai }=7-4 \\
\text { Nilai }=3-0\end{aligned}$ & 6 & $\begin{array}{l}\text { Geologi Bagus dan } \\
\text { memenuhi syarat }\end{array}$ & 9 & 0.54 & $\begin{array}{l}\text { Keandalan teknis } \\
\text { memenuhi syarat }\end{array}$ & 10 & 0.6 \\
\hline $\begin{array}{l}6 \text { Jalan masuk ke lokasi site (m) } \\
\text { a. } 0-300 \\
\text { b. } 300-1000 \\
\text { c. }>1000\end{array}$ & $\begin{aligned} \text { Nilai } & =10-8 \\
\text { Nilai } & =7-4 \\
\text { Nilai } & =3-0\end{aligned}$ & 8 & Sudah ada jalan masuk & 10 & 0.80 & Sudah ada jalan masuk & 5 & 0.40 \\
\hline $\begin{array}{l}7 \text { Kondisi DAS } \\
\text { a. Baik } \\
\text { b. Sedang } \\
\text { c. Jelek } \\
\end{array}$ & $\begin{aligned} \text { Nilai }=10-8 \\
\text { Nilai }=7-4 \\
\text { Nilai }=3-0\end{aligned}$ & 5 & Sedang & 7 & 0.35 & Sedang & 6 & 0.3 \\
\hline $\begin{array}{l}8 \text { Jarak daerah layanan }(\mathrm{m}) \\
\text { a. } \leq 1000 \\
\text { b. } 1000-2000 \\
\text { c. }>2000\end{array}$ & $\begin{array}{l}\text { Nilai }=10-8 \\
\text { Nilai }=7-4 \\
\text { Nilai }=3-0\end{array}$ & 8 & kurang dari $1 \mathrm{~km}$ & 9 & 0.72 & kurang dari $1 \mathrm{~km}$ & 8 & 0.64 \\
\hline $\begin{array}{l}9 \text { Lokasi embung } \\
\text { a. Cekungan } \\
\text { b. Curah/alur sungai } \\
\text { c. Sungai } \\
\end{array}$ & $\begin{aligned} \text { Nilai } & =10-8 \\
\text { Nilai } & =7-4 \\
\text { Nilai } & =3-0\end{aligned}$ & 6 & Sungai & 9 & 0.54 & Cekungan & 10 & 0.6 \\
\hline $\begin{array}{l}10 \text { Sistem distribusi air } \\
\text { a. Gravitasi } \\
\text { b. Diambil sendiri } \\
\text { c. Pompa }\end{array}$ & $\begin{aligned} \text { Nilai } & =10-8 \\
\text { Nilai } & =7-4 \\
\text { Nilai } & =3-0\end{aligned}$ & 8 & Gravitasi & 8 & 0.64 & Gravitasi & 9 & 0.72 \\
\hline
\end{tabular}




\begin{tabular}{|c|c|c|c|c|c|c|c|c|}
\hline \multirow{2}{*}{ KETERANGAN } & \multirow{2}{*}{$\begin{array}{l}\text { PENENTUAN } \\
\text { PENELITIAN }\end{array}$} & \multirow{2}{*}{$\begin{array}{c}\text { ВОВОТ (B) } \\
\text { (\%) }\end{array}$} & \multicolumn{3}{|c|}{ TANOUNG PALASTIMUR } & \multicolumn{3}{|c|}{ BUNYU } \\
\hline & & & IDENIIIIKASI & NILAI (N) & $(\mathrm{NX} B) / \mathbf{1 0 0}$ & IDENIIIFIKASI & NILAI (N) & $(N \times B) / 100$ \\
\hline ASPEK TEKNIS & & 45 & & & & & & \\
\hline $\begin{array}{l}1 \text { Bentang }(\mathrm{x} \mathrm{m}) \\
\text { a. } 30-70 \\
\text { b. } 70-100 \\
\text { c. } x>100 \\
\end{array}$ & $\begin{aligned} \text { Nilai }=10-8 \\
\text { Nilai }=7-4 \\
\text { Nilai }=3-0\end{aligned}$ & 3 & $\mid \begin{array}{c}\text { Panjang bentang sekitar } \\
100 \mathrm{~m}\end{array}$ & 7 & 0.21 & $\begin{array}{c}\text { Panjang bentang sekitar } \\
100 \mathrm{~m}\end{array}$ & 7 & 0.21 \\
\hline $\begin{array}{l}2 \text { Volume tampungan }\left(\mathrm{m}^{3}\right) \\
\text { a. }>100.000 \\
\text { b. } 40.000-100.000 \\
\text { c. }<40.000\end{array}$ & $\begin{aligned} \text { Nilai }=10-8 \\
\text { Nilai }=7-4 \\
\text { Nilai }=3-0\end{aligned}$ & 8 & $\begin{array}{l}\text { Volume tampungan } \\
\text { sekitar } 301.888 \mathrm{~m}^{3}\end{array}$ & 8 & 0.64 & $\begin{array}{l}\text { Volume tampungan } \\
\text { sekitar } 145.292 \mathrm{~m}^{3}\end{array}$ & 8 & 0.64 \\
\hline $\begin{array}{l}3 \text { Jarak ketersediaan material }(\mathrm{m}) \\
\text { A. Batu } \\
\text { a. } 0-500 \\
\text { b. } 500-1000 \\
\text { c. }>1000\end{array}$ & $\begin{aligned} \text { Nilai }=10-8 \\
\text { Nilai }=7-4 \\
\text { Nilai }=3-0\end{aligned}$ & 3 & $\begin{array}{l}\text { Ketersediaan batu } \\
\text { sekitar } 1000 \mathrm{~m}\end{array}$ & 6 & 0.18 & $\begin{array}{l}\text { Ketersediaan batu } \\
\text { sekitar } 1000 \mathrm{~m}\end{array}$ & 6 & 0.18 \\
\hline $\begin{array}{l}\text { B. Tanah } \\
\text { a. } 0-500 \\
\text { b. } 500-1000 \\
\text { c. }>1000\end{array}$ & $\begin{aligned} \text { Nilai }=10-8 \\
\text { Nilai }=7-4 \\
\text { Nilai }=3-0\end{aligned}$ & 6 & $\begin{array}{c}\text { Ketersediaan Tanah }< \\
500 \mathrm{~m}\end{array}$ & 5 & 0.3 & $\begin{array}{c}\text { Ketersediaan Tanah < } \\
500 \mathrm{~m}\end{array}$ & 5 & 0.30 \\
\hline $\begin{array}{l}4 \text { Baseflow } \\
\text { a. Tidak ada } \\
\text { b. Ada sampai bulan Juni } \\
\text { c. Ada sepanjang tahun } \\
\end{array}$ & $\begin{aligned} \text { Nilai }=10-8 \\
\text { Nilai }=7-4 \\
\text { Nilai }=3-0\end{aligned}$ & 3 & $\begin{array}{c}\text { Ada Baseflow sebesar } \\
0,047 \mathrm{~m} 3 / \mathrm{dt}\end{array}$ & 3 & 0.09 & $\begin{array}{c}\text { Ada Baseflow sebesar } \\
0,047 \mathrm{~m} 3 / \mathrm{dt}\end{array}$ & 3 & 0.09 \\
\hline $\begin{array}{l}5 \text { Kondisi geologi } \\
\text { a. Permeabel } \\
\text { b. Semi Permeabel } \\
\text { c. Impermeabel }\end{array}$ & $\begin{aligned} \text { Nilai }=10-8 \\
\text { Nilai }=7-4 \\
\text { Nilai }=3-0\end{aligned}$ & 6 & $\begin{array}{l}\text { Geologi Bagus dan } \\
\text { memenuhi syarat }\end{array}$ & 8 & 0.48 & $\begin{array}{l}\text { Geologi Bagus dan } \\
\text { memenuhi syarat }\end{array}$ & 8 & 0.48 \\
\hline $\begin{array}{l}6 \text { Jalan masuk ke lokasi site }(\mathrm{m}) \\
\text { a. } 0-300 \\
\text { b. } 300-1000 \\
\text { c. }>1000\end{array}$ & $\begin{aligned} \text { Nilai }=10-8 \\
\text { Nilai }=7-4 \\
\text { Nilai }=3-0\end{aligned}$ & 8 & Sudah ada jalan masuk & 4 & 0.32 & Sudah ada jalan masuk & 4 & 0.32 \\
\hline $\begin{array}{l}7 \text { Kondisi DAS } \\
\text { a. Baik } \\
\text { b. Sedang } \\
\text { c. Jelek }\end{array}$ & $\begin{aligned} \text { Nilai }=10-8 \\
\text { Nilai }=7-4 \\
\text { Nilai }=3-0\end{aligned}$ & 5 & Baik & 8 & 0.4 & Baik & 8 & 0.4 \\
\hline $\begin{array}{l}8 \text { Jarak daerah layanan }(\mathrm{m}) \\
\text { a. } \leq 1000 \\
\text { b. } 1000-2000 \\
\text { c. }>2000\end{array}$ & $\begin{aligned} \text { Nilai }=10-8 \\
\text { Nilai }=7-4 \\
\text { Nilai }=3-0\end{aligned}$ & 8 & kurang dari $1 \mathrm{~km}$ & 8 & 0.64 & kurang dari $1 \mathrm{~km}$ & 8 & 0.64 \\
\hline $\begin{array}{l}9 \text { Lokasi embung } \\
\text { a. Cekungan } \\
\text { b. Curah/alur sungai } \\
\text { c. Sungai }\end{array}$ & $\begin{aligned} \text { Nilai }=10-8 \\
\text { Nilai }=7-4 \\
\text { Nilai }=3-0\end{aligned}$ & 6 & Curah/alur sungai & 5 & 0.3 & Curah/alur sungai & 5 & 0.3 \\
\hline $\begin{array}{l}10 \text { Sistem distribusi air } \\
\text { a. Gravitasi } \\
\text { b. Diambil sendiri } \\
\text { c. Pompa } \\
\end{array}$ & $\begin{aligned} \text { Nilai }=10-8 \\
\text { Nilai }=7-4 \\
\text { Nilai }=3-0\end{aligned}$ & 8 & Gravitasi & 8 & 0.64 & Gravitasi & 8 & 0.64 \\
\hline
\end{tabular}

Tabel 3. Urutan Lokasi Embung Berdasarkan Nilai Lokasi Berdasarkan Aspek Teknis \& Non Teknis

\begin{tabular}{|c|c|c|c|c|c|c|c|c|}
\hline \multirow{2}{*}{ KETERANGAN } & \multirow{2}{*}{$\begin{array}{l}\text { PENENTUAN } \\
\text { PENELTIAN }\end{array}$} & \multirow{2}{*}{$\begin{array}{c}\text { ВОВОт (B) } \\
\text { (\%) }\end{array}$} & \multicolumn{3}{|c|}{ TANDUNG PALAS } & \multicolumn{3}{|c|}{ TANOUNG PALAS TENGAH } \\
\hline & & & IDENIIFIKASI & NILAI (N) & ( NX B)/100 & IDENTIFIKASI & NILAI (N) & $(\mathrm{NXB}) / 100$ \\
\hline ASPEK NON TEKNIS & & 55 & & & & & & \\
\hline $\begin{array}{l}1 \text { Manfaat } \\
\text { a. Air baku dan irigasi } \\
\text { b. Air baku } \\
\text { c. Irigasi } \\
\end{array}$ & $\begin{array}{l}\text { Nilai }=10-8 \\
\text { Nilai }=7-4 \\
\text { Nilai }=3-0\end{array}$ & 11 & Air Irigasi dan air baku & 9 & 0.99 & Air Irigasi dan air baku & 10 & 1.1 \\
\hline $\begin{array}{l}2 \text { Kondisi masyarakat penerima manfaat } \\
\text { a. Pra sejahtera } \\
\text { b. Sejahtera I } \\
\text { c. Sejahtera II }\end{array}$ & $\begin{array}{l}\text { Nilai }=10-8 \\
\text { Nilai }=7-4 \\
\text { Nilai }=3-0\end{array}$ & 4 & $\begin{array}{c}\text { masyarakat Pra } \\
\text { sejahtera }\end{array}$ & 8 & 0.32 & $\begin{array}{c}\text { masyarakat Pra } \\
\text { sejahtera }\end{array}$ & 8 & 0.32 \\
\hline $\begin{array}{l}3 \text { Pencapaian lokasi } \\
\text { a. Bisa dengan roda } 4 \\
\text { b. Bisa dengan roda } 2 \\
\text { c. Jalan kaki }\end{array}$ & $\begin{array}{l}\text { Nilai }=10-8 \\
\text { Nilai }=7-4 \\
\text { Nilai }=3-0\end{array}$ & 5 & $\begin{array}{c}\text { Bisa dengan roda } 4 \\
\text { namun ditambah jalan } \\
\text { kaki sejauh } 200 \mathrm{~m}\end{array}$ & 9 & 0.45 & $\begin{array}{l}\text { Bisa dengan roda } 4 \\
\text { namun ditambah jalan } \\
\text { kaki sejauh } 500 \mathrm{~m}\end{array}$ & 8 & 0.40 \\
\hline $\begin{array}{l}4 \text { Kepemilikan tanah } \\
\text { a. Pemerintah } \\
\text { b. Pemerintah dan penduduk } \\
\text { c. Penduduk } \\
\end{array}$ & $\begin{array}{l}\text { Nilai }=10-8 \\
\text { Nilai }=7-4 \\
\text { Nilai }=3-0\end{array}$ & 4 & $\begin{array}{l}\text { Pemerintah dan } \\
\text { Penduduk }\end{array}$ & 7 & 0.28 & $\begin{array}{l}\text { Pemerintah dan } \\
\text { Penduduk }\end{array}$ & 7 & 0.28 \\
\hline $\begin{array}{l}5 \text { Dampak lingkungan } \\
\text { a. Dampak positif } \\
\text { b. Tidak menimbulkan dampak } \\
\text { c. Dampak negatif }\end{array}$ & $\begin{array}{l}\text { Nilai }=10-8 \\
\text { Nilai }=7-4 \\
\text { Nilai }=3-0\end{array}$ & 7 & Dampak Positif & 8 & 0.56 & Dampak Positif & 8 & 0.56 \\
\hline $\begin{array}{l}6 \text { Tanggapan masyarakat } \\
\text { a. Menerima } \\
\text { b. Acuh tak acuh } \\
\text { c. Tidak menerima }\end{array}$ & $\begin{array}{l}\text { Nilai }=10-8 \\
\text { Nilai }=7-4 \\
\text { Nilai }=3-0\end{array}$ & 8 & Menerima & 8 & 0.64 & Menerima & 8 & 0.64 \\
\hline $\begin{array}{l}7 \text { Prioritas kebutuhan penduduk } \\
\text { a. Sangat membutuhkan } \\
\text { b. Membutuhkan } \\
\text { c. Tidak Membutuhkan }\end{array}$ & $\begin{aligned} & \text { Nilai }= 10-8 \\
& \text { Nilai }=7-4 \\
& \text { Nilai }=3-0\end{aligned}$ & 6 & Sangat membutuhkan & 9 & 0.54 & Sangat membutuhkan & 9 & 0.54 \\
\hline $\begin{array}{l}8 \text { Kemudahan dalam pembebasan lahan } \\
\text { a. Tanpa ganti rugi } \\
\text { b. Mudah ganti rugi } \\
\text { c. Sulit } \\
\end{array}$ & $\begin{array}{l}\text { Nilai }=10-8 \\
\text { Nilai }=7-4 \\
\text { Nilai }=3-0\end{array}$ & 10 & Mudah ganti rugi & 5 & 0.50 & Mudah ganti rugi & 7 & 0.70 \\
\hline
\end{tabular}




\begin{tabular}{|c|c|c|c|c|c|c|c|c|}
\hline \multirow{2}{*}{ KETERANGAN } & \multirow{2}{*}{$\begin{array}{l}\text { PENENTUAN } \\
\text { PENELTIIAN }\end{array}$} & \multirow{2}{*}{$\begin{array}{c}\text { ВОВОт (В) } \\
\text { (\%) }\end{array}$} & \multicolumn{3}{|c|}{ TANOUNG PALASTIMUR } & \multicolumn{3}{|c|}{ BUNYU } \\
\hline & & & IDENIIFIKASI & NILAI (N) & ( NXB)/100 & IDENTIFIKASI & NILAI (N) & $(N \times B) / 100$ \\
\hline ASPEK NON TEKNIS & & 55 & & & & & & \\
\hline $\begin{array}{l}1 \text { Manfaat } \\
\text { a. Air baku dan irigasi } \\
\text { b. Air baku } \\
\text { c. Irigasi } \\
\end{array}$ & $\begin{array}{l}\text { Nilai }=10-8 \\
\text { Nilai }=7-4 \\
\text { Nilai }=3-0\end{array}$ & 11 & Air Irigasi dan air baku & 8 & 0.88 & Air Irigasi dan air baku & 10 & 1.1 \\
\hline $\begin{array}{l}2 \text { Kondisi masyarakat penerima manfaat } \\
\text { a. Pra sejahtera } \\
\text { b. Sejahtera I } \\
\text { c. Sejahtera II } \\
\end{array}$ & $\begin{array}{l}\text { Nilai }=10-8 \\
\text { Nilai }=7-4 \\
\text { Nilai }=3-0\end{array}$ & 4 & $\begin{array}{l}\text { masyarakat Pra } \\
\text { sejahtera }\end{array}$ & 8 & 0.32 & $\begin{array}{l}\text { masyarakat Pra } \\
\text { sejahtera }\end{array}$ & 8 & 0.32 \\
\hline $\begin{array}{l}3 \text { Pencapaian lokasi } \\
\text { a. Bisa dengan roda } 4 \\
\text { b. Bisa dengan roda } 2 \\
\text { c. Jalan kaki }\end{array}$ & $\begin{array}{l}\text { Nilai }=10-8 \\
\text { Nilai }=7-4 \\
\text { Nilai }=3-0\end{array}$ & 5 & Jalan Kaki & 3 & 0.15 & $\begin{array}{c}\text { Bisa dengan roda } 4 \\
\text { namun ditambah jalan } \\
\text { kaki sejauh } 500 \mathrm{~m}\end{array}$ & 8 & 0.03 \\
\hline $\begin{array}{l}4 \text { Kepemilikan tanah } \\
\text { a. Pemerintah } \\
\text { b. Pemerintah dan penduduk } \\
\text { c. Penduduk }\end{array}$ & $\begin{array}{l}\text { Nilai }=10-8 \\
\text { Nilai }=7-4 \\
\text { Nilai }=3-0\end{array}$ & 4 & $\begin{array}{l}\text { Pemerintah dan } \\
\text { Penduduk }\end{array}$ & 7 & 0.28 & $\begin{array}{l}\text { Pemerintah dan } \\
\text { Penduduk }\end{array}$ & 7 & 0.28 \\
\hline $\begin{array}{l}5 \text { Dampak lingkungan } \\
\text { a. Dampak positif } \\
\text { b. Tidak menimbulkan dampak } \\
\text { c. Dampak negatif }\end{array}$ & $\begin{array}{l}\text { Nilai }=10-8 \\
\text { Nilai }=7-4 \\
\text { Nilai }=3-0\end{array}$ & 7 & $\begin{array}{c}\text { Dampak positif, bisa } \\
\text { menjadi area konservasi }\end{array}$ & 10 & 0.7 & Dampak Positif & 8 & 0.56 \\
\hline $\begin{array}{l}6 \text { Tanggapan masyarakat } \\
\text { a. Menerima } \\
\text { b. Acuh tak acuh } \\
\text { c. Tidak menerima }\end{array}$ & $\begin{array}{l}\text { Nilai }=10-8 \\
\text { Nilai }=7-4 \\
\text { Nilai }=3-0\end{array}$ & 8 & Menerima & 8 & 0.64 & Menerima & 8 & 0.64 \\
\hline $\begin{array}{l}7 \text { Prioritas kebutuhan penduduk } \\
\text { a. Sangat membutuhkan } \\
\text { b. Membutuhkan } \\
\text { c. Tidak Membutuhkan } \\
\end{array}$ & $\begin{array}{l}\text { Nilai }=10-8 \\
\text { Nilai }=7-4 \\
\text { Nilai }=3-0\end{array}$ & 6 & Sangat membutuhkan & 9 & 0.54 & Sangat membutuhkan & 9 & 0.54 \\
\hline $\begin{array}{l}8 \text { Kemudahan dalam pembebasan lahan } \\
\text { a. Tanpa ganti rugi } \\
\text { b. Mudah ganti rugi } \\
\text { c. Sulit } \\
\end{array}$ & $\begin{array}{l}\text { Nilai }=10-8 \\
\text { Nilai }=7-4 \\
\text { Nilai }=3-0\end{array}$ & 10 & Mudah ganti rugi & 7 & 0.70 & Mudah ganti rugi & 7 & 0.70 \\
\hline
\end{tabular}

Sehingga diperoleh rangking hasil penilaian, sebagai berikut ;

\begin{tabular}{|c|l|c|c|}
\hline NO. & \multicolumn{1}{|c|}{ NAMA EMBUNG } & SKOR TOTAL & RANKING \\
\hline \hline 1 & EMBUNG TANJUNG PALAS & 9.73 & 1 \\
\hline 2 & EMBUNG TANJUNG PALAS TENGAH & 9.17 & 2 \\
\hline 3 & EMBUNG TANJUNG PALAS TIMUR & 8.41 & 3 \\
\hline 4 & EMBUNG BUNYU & 8.37 & 4 \\
\hline
\end{tabular}

Tabel 4. Neraca Air Embung Tanjung Palas

EMBUNG TANJUNG PALAS

EMBUNG TANJUNG PALAS - KABUPATEN BULUNGAN, KALIMANTAN UTARA

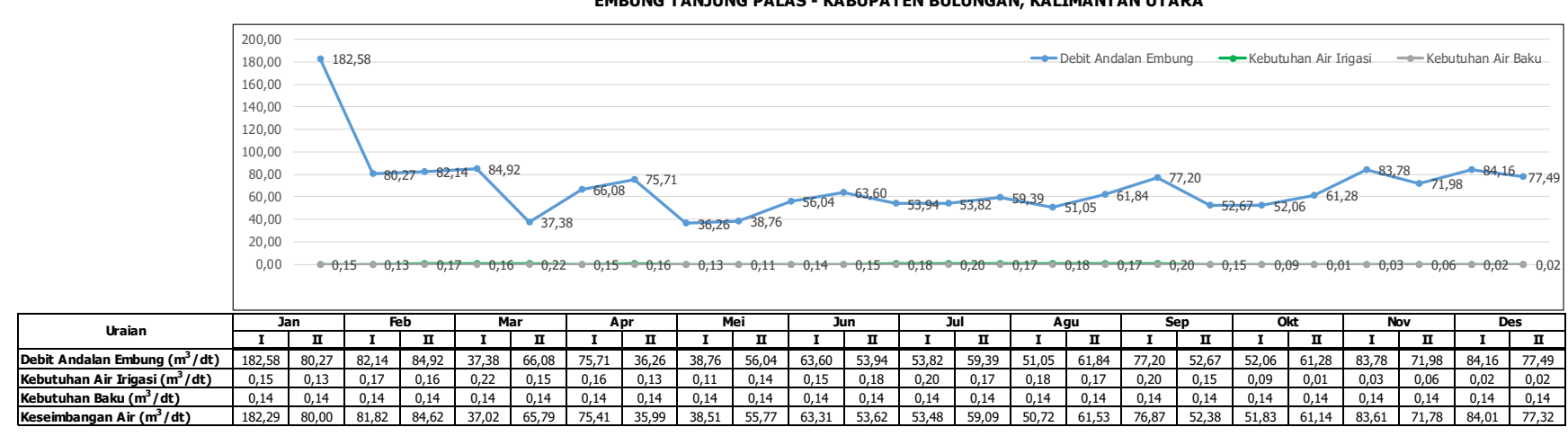

Dari Tabel 3 (Neraca Air Embung Tanjung Palas) dapat dijelaskan bahwa untuk sepanjang bulan tidak terjadi kekurangan air untuk kebutuhan air irigasi untuk $100 \mathrm{Ha}$ dan air bersih sampai tahun 2042. Ini karena ketersediaan air di embung dapat mencukupi kebutuhan yang di manfaatkan di hilir embung. 


\section{KESIMPULAN}

Berdasarkan kriteria pemilihan lokasi embung dengan kedua aspek, nilai modifikasi bobot pertimbangan dan pertimbangan salah satu aspek saja maka dapat disimpulkan nilai yang tertinggi adalah Embung Tanjung Palas. Selanjutnya untuk neraca air, tidak terjadi kekurangan air, baik untuk tahun dasar perencanaan (2019) maupun proyeksi sampai tahun 2042. Artinya di lokasi ini perlu dibangun embung yang berfungsi untuk menampung air saat musim penghujan dan mendistribusikannya pada saat musim kemarau.

\section{DAFTAR PUSTAKA}

[1] Anonim, 1994. Kriteria Perencanaan Ditjen Cipta Karya Dinas PU, Jakarta: Dinas Pekerjaan Umum.

[2] Asdak, C. 1995. Hidrologi dan Pengelolaan Daerah Aliran Sungai. Yogyakarta: Gadjah Mada University Press.

[3] Asdak, C. 2007. Hidrologi dan Pengendalian Daerah Aliran Sungai. Yogyakarta: Gadjah Mada University Press.

[4] Departemen Pekerjaan Umum. 1994. Pedoman Kriteria desain Embung Kecil Untuk Daerah Semi Kering di Indonesia. Bandung: Departemen Pekerjaan Umum.

[5] Harto, Sri.1993. Analisis Hidrologi. Jakarta: PT Gramedia Pustaka Utama

[6] Hadisusanto, N. 2010. Aplikasi Hidrologi. Yogyakarta: Mediautama.

[7] Kurniawan, Rizal A. 2009. Studi Potensi Ketersediaan Air Untuk Pemenuhan Kebutuhan Air Baku dalam Perencanaan Embung Kasinan Kota Batu. Skripsi. Tidak Diterbitkan. Jurusan Teknik Pengairan Universitas Brawijaya Malang.

[8] L., Lily Montarcih. 2010. Hidrologi Terapan. Malang: CV. Citra Malang.

[9] Linsley, Ray K. dan Yoseph B. Franzini. 1996. Teknik Sumber Daya Air. Jilid 1. Jakarta: Erlangga.

[10] Muliakusumah, Sutarsih. 2000. Proyeksi Penduduk. Jakarta: Fakultas Ekonomi UI.

[11] Soemarto, CD. 1995. Hidrologi Teknik. Jakarta: Usaha Erlangga.

[12] Soewarno. 1995. Hidrologi-Aplikasi Metode Statistik untuk Analisa Data. Bandung: Nova.

[13] Subarkah, Imam. 1980. Hidrologi: untuk perencanaan bangunan air. Bandung: Idea Dharma

[14] Sosrodarsono, Suyono dan Kensaku Takeda, 1987. Hidrologi Untuk Pengairan. Jakarta: PT Pradnya Paramita.

[15] Sosrodarsono, Suyono dan Kensaku Takeda. 1977. Bendungan Type Urugan. Jakarta: PT Pradnya Paramita.

[16] Soedibyo, 1993. Teknik Bendungan. Jakarta: PT Pradnya Paramita.

[17] Triatmodjo, Bambang. 2010. Hidrologi Terapan. Yogyakarta: Beta Offset 